\title{
The Effectiveness of Co-Management Practices: The Case of Small-Scale Fisheries in Sri Lanka
}

\author{
Vyddiyaratnam Pathmanandakumar* \\ Department of Geography, Eastern University of Sri Lanka, Sri Lanka
}

Submission: October 22, 2017; Published: March 23, 2018

*Corresponding author: Vyddiyaratnam Pathmanandakumar, Lecturer, Department of Geography, Eastern University of Sri Lanka, Vantharumoolai Batticaloa, Sri Lanka, Tel: +94777446630; Email: pathmananth@gmail.com

\begin{abstract}
Majority of the fishers in Sri Lanka have involved in small-scale fishing and facing difficulties to cope with coastal population. The fish stocks are declining that threaten reproductive capacity. If this is continuing, the provision of food and livelihoods to the poor fishers will be in trouble in future. There should be radical changes in the fisheries policies. In addition, fundamental reforms should be made to manage small-scale fisheries smoothly. Small-scale fisheries in Sri Lanka heavily rely on outside controls which lead to unsustainable of the sector. Managers should be away from making obstacle in the form of management measures. Scientists should involve directly with fishery management agencies to understand the needs of the agencies. Resource managers must be involved in regulating fishing output by imposing limitation on entry, numbers of vessels, short-fishing seasons etc. In the future, it is expected that proper management of small-scale fisheries will provide sustainable benefits to the fishing communities in Sri Lanka.
\end{abstract}

\section{Introduction}

The world's capture fisheries are divided into small-scale fisheries and large-scale fisheries or alternatively subsistence fisheries, artisanal fisheries and industrial fisheries based on the scale of the technology used [1]. Small scale fishing is one of the oldest human livelihood activities, found around the world, and key source of global food production [2,3]. However, Smallscale fisheries are exploited all around the world as a result of week governance, poor management, corruption, open access, harmful fishing practices [3]. world Small-scale fisheries play an important role in national and local economies [4], but it is poorly planned, regulated, inadequately funded and neglected as compared with world food economy [5].

Sri Lanka has long history of fishing and has been major contributor to livelihood of the coastal communities. The fisheries sector in Sri Lanka consists of coastal fisheries, offshore fisheries and inland fisheries and aquaculture. Sri Lanka has 517,000sq (200 nautical) Exclusive Economic Zone which is rich in marine resources. Further, more than 45 major brackish water lagoons and estuaries are located around the Sri Lanka. Apart from this, there are 489,000 ha of inland water bodies including tanks and reservoirs.

The vast majority of fishers are involved in small scale fisheries in Sri Lanka [6]. It is nottechnologically advanced as more industrial fisheries and uses complex traditional management and knowledge system. Small-scale fisheries are typically more complex and have strong interaction with coastal communities in order to pursuit multitude objectives. Sri Lanka has a huge potential to expand fisheries sector to boost its economy. More than 560,000 people have been employed in fisheries sector. It provides livelihood for 2.6 million people, ways to generate income, foreign exchange earnings and natural proteins to the people. Marine fish production was 334,390 Mt in 2016 while inland fish production was $50,220 \mathrm{Mt}$. The contribution of fisheries sector to GDP was $1.7 \%$ in 2016 [6]. The total export value and quantity of fish and fish products was $18,458 \mathrm{Mt}$ and $12,982 \mathrm{Mt}$ respectively [6]. It is essential to maintain a protein level through per capita fish consumption $(22 \mathrm{Kg}$ per year) to ensure acceptable nutrition intake in Sri Lanka. The Ministry of Fisheries and Aquatic Resources Development has taken steps to increase the national fish production.

Despite of this importance, small-scale fisheries are not properly understood in Sri Lanka and lacks with straightforward definition. Small-scale fisheries have the potential to contribute to reducing poverty and improve food security in Sri Lanka. The proper management of small-scale fisheries will minimize the loss of biodiversity and coastal ecosystem [7]. Solutions can be complex, but underlying courses can be better understood when explained in familiar terms. Therefore this study evaluates the effectiveness of co-management practices in small scale fisheries in Sri Lanka. 


\section{Methodology}

This paper has been prepared based on desk review. Different theoretical and empirical evidences were reviewed to understand co-management practice in small-scale fisheries and based on that, effectiveness of co-management practices in small scale fisheries in Sri Lanka has been explored [8].

\section{Defining "small-scale fisheries"}

The term "Small-scale fisheries" is broadly referred the world's fishers and fishing vessels. Scholars agree that a universal definition is not either possible or useful. Smallscale fisheries are diverse, dynamic, attached to livelihoods and culture of the local communities. Efforts have been given to differentiate small-scale fisheries from large-scale fisheries through scientific literatures, but its diversity makes difficult to differentiate. The words interchangeably used in smallscale fisheries are "Artisanal, local, coastal, traditional, small, subsistence, nonindustrial, low tech and poor. Before 1980s, research on small-scale fisheries mainly focused on biological aspects, but ignored [9]. Later, research on small-scale fisheries included socio-economic aspects of fishing communities.

Many developing countries have taken steps to improve objectives and policies for small-scale fisheries as total catches have declined throughout the tropics. The regular objectives of small-scale fisheries were maximizing catches, generating employment, sustaining stocks but later those objectives shifted to management of marine resources to achieve sustainable development through improved ecological and human wellbeing.

Small-scale fisheries face many challenges such as week governance, local organizations, unstable socio-economic conditions, environmental and ecosystem degradation [10]. Week governance is an important underlying cause of overfishing in Sri Lanka that motivated by corruption, poor stakeholder's participation, poor enforcement, week institutional capacity, overcapacity of fishing fleets and illegal fishing. There are mismatch between institutional framework and unique features of small-scale fisheries. In recent decades, governance reforms have mainly concentrated on administrative decentralization. Local people and institutions have gained strong administrative power on small-scale fisheries through these reforms in Sri Lanka.

\section{Defining co-management}

Co-management is a relationship between a resource-user group and another organization or entity (usually a government agency) for the purposes of fisheries management in which some degree of responsibility and or authority is conferred to both parties [11]. Interest in co-management has increased globally as other management process has failed to create linkages between public sector, private sector and communities. Therefore "Co- management can broadly be defined as an arrangement where management responsibility is shared between the government and fishing communities. It can be viewed as a set of institutional and organizational arrangement that define the cooperation among the fisheries administration and relevant fishing communities" [12].

Further definition is given by Jentoft that "co-management can be defined as "a collaborative and participatory process of regulatory decision-making between representatives of usergroups, government agencies, research institutions, and other stakeholders. Power sharing and partnership are an essential part of this definition" [13]. Small-scale fisheries require comanagement because of the conditions under which such fishing takes place. Participants' behavior will be observed internally and rules will be enforced. Small-scale fisheries in the near-shore are in need of effective management as it faces effects of pollution, habitat destruction and competition for land. These effects are intensified by population shifts to coastal area. Co-management is seen as a remedy to problems caused by other management arrangements and the attention is mainly paid on the benefits of co-management rather than its costs or requirements of implementing new process. However, effective co-management of small-scale fisheries requires some conditions.

The benefits accruing from fisheries co-management can be viewed from both co-managers' prospective and resource use community's perspective. From the managers' point of view, it includes achieving sustainable finishing, reducing cost of fisheries management [14]. Fisheries management regulations cannot be successful without support from the fishermen because fishermen very often break the regulation and make the management in fisheries more expensive [14]. From the resource use community's point of view, fishers get very limited benefits.

\section{Different type of co-management}

Despite the technical definition of "co-management", Jentoft 1989 gives a simple definition as the sharing of responsibility or authority between the government and local resources users to manage resources [15]. A broad management arrangements and responsibilities are covered in "co-management" in which the government and resources users heavily depend on and will vary. Fisheries co-management requires a certain level of involvement and communication between government and fishers and well-established organizational structures and institutions with decision making power in local fisheries management. Several degrees of co-management could be observed as Berkes [3] noted. Instructive type of management which has only minimal exchange of information between government and users. Consultative type of management where a mechanism exists for consultation between government and users but decision will be taken by the government. This type of management can be considered true co-management. However, cooperative types of managements are closer to real definition of co-management where governments and users cooperate on equal basis in the management and decision making process. 
On the other hand, co-management is the one in which users advise the government of decision to be taken and government endorse them. User groups are responsible for informing government of their decision and government has the delegated power on user groups in innovative co-management. Local users have total decision making power in community based management. However, some authors argue that community based management will not be included in the concept of co-management [16]. It is very vital to understand that this typology is just a simplification of very complex management system. Many activities can be managed under different type of co-management at different stages. Therefore co-management is the one that covers a broad range of decision making between government and resource users.

\section{Management of small-scale fisheries}

Small-scale fisheries will be unsuccessful if a single institution can control it. Top-down management system is used by the government in many small-scale fisheries with no or little participation of fishers groups [17]. On the other hand, it is also problematic when many people or organizations involve in fishery governance. Generally, fishery governance requires a good leadership to be successful [10]. Experience shows that co-management is beneficial over decision making and strategy of small-scale fisheries [18]. A co-management system allows empowering stakeholders to develop a plan with clear objectives on how to bring forward the fishery. Stronger engagement with fishers will bring better output from the small-scale fisheries. In addition, arrangement should be made to give feedback and concerns to managers.

\section{Controls on output}

The managers of small-scale fisheries in several developing countries largely focus on output controls (Size limits) rather than input controls (vessel limits, seasonal control) [19]. Output should not be taken onto account to control fisheries. Size limits has been used as a classical management strategy to control overfishing [20]. However, recent studies argue that large individuals contribute to reproduction so that selectivity for large individuals may negatively affect fish population [21]. Multi species pre-dominated small-scale fisheries in developing countries where size limits are complicated [22]. Legal size can be confusing for fishers. It is not physically easy to inspect harvested fish. Alternatively, incentives can be given for fishers to voluntarily introduce size selectivity as no good market for small size fish [19]. Management bodies lack technical capacity to implement catch quotas effectively [19]. Fishery stock requires 5 to 10 years to recover but some marine resource may need much more time to rebuild population. In some cases, fishery bans relax too early before it got matured and become dense again. Most importantly, if a ban has been imposed due to overfishing then the management system must be substantially changed before the ban is lifted to resume fishing.

\section{Benefits from co-management}

The benefits from co-management can be looked from different point of view. On the government side, it ranges from achieving the management objectives of sustainable fisheries to reduced cost of fisheries management [14]. The world-wide experiences have proved that it is hard to achieve the successful co-management practice in fisheries without support from fishers. Passing and enforcing regulations in terms of fishing and fisheries management makes its management more expensive $[14,23]$. Fishers will be given the opportunities to do grand work as they receive benefit materially from fishing. Lot of financial supports will be arranged to fishers to uplift their livelihoods. Further, some mechanism will be made to boost the income of fishers that will enhance the livelihood of fishers. It is not quite hard to reap benefits from fisheries as co-management introduced in various stages of fisheries.

\section{Exploitation of small-scale fisheries}

Set of element that accelerates exploitation of small-scale fisheries. Open access is one of the key issues in small-scale fisheries in developing countries which permit too many fishers to involve in the fishery [24]. Fishers strongly influence the exploitation of resources and exploit too fast and rate of exploitation is not control enough to regulate [25]. Involvement in fishery rises when economic returns and sustainability of fish stock decline sharply. It has been accelerated by over capitalization of fisheries with large boats and fleets [26]. The impacts of fishing right have positive and negative socioeconomic implications. Therefore, difficult decision must be made in terms of fishing rights. Group fishing rights and territorial user rights will assist small-scale fishers to improve preferential access rights on coastal area. In some cases, community property rights and small-scale fisheries suit well [27]. Group fishing rights and territorial user rights require capability to co-manage the resources, restriction on group membership and ability to limit access. However, social context in small-scale fisheries don't allow imposing limited entry rule to reduce number of fishers [26]. Denying access for fishers on traditionally fished resources may also create economic struggle. More attention needs to pay on control of fishing efforts such as limits on boat size, fishing season, controlling fishing within sustainable limits [19]. Restriction on boats size can prevent fisheries form becoming semi-industrial. Vessel restriction on small-scale fisheries may also give benefits, but hard to implement in certain fisheries [26]. Seasonal closure and limits on number of fishing days are applied in many areas to control over exploitation of fish resources [17]. Seasonal closure will be in force during the reproductive seasons rather than introduce to reduce annual fishing efforts. Very short fishing days (a few days) is great success in some cases [28]. Generally, short fishing days is more suitable for export commodity. The more important thing is that fishing efforts should be able to achieve sustainability. In certain situations, efforts to short out 
these issues are socially unpopular. Anyway, it is believed that activities on coastal area will have great ecological and social consequences in the long-term.

\section{Who controls management of small-scale fisheries?}

It is a big issue in fisheries that the management models are designed by professionals who have no or less experiences with managing fisheries and unaware the realities that exist in developing countries. In many cases, the managerial advices from NGOs or scientists don't express fishers' perspectives. In operation, scientists and NGOs solely decide the management strategy of small-scale fisheries. Fisheries managers are just in a position to implement it. The arguments made by scientists are biased towards certain aspects of management measures. Particularly, marine conservation and management pay more attention on marine reserves. Lot of scientific literatures is available as to marine reserves. Many of the literatures propose marine reserves as a solution for fisheries management [29]. NGOs that involve in fisheries management push for the use of "marine protected area" in low-income countries. Overweighted scientific advice on management issues may lead to imbalance management and that may impacts sustainability of fisheries.

\section{Effectiveness of co-management practice in small scale fisheries in Sri Lanka}

Fisheries cooperative society has been in practice for long time in Sri Lanka. Fishers should be a member of this community based organization (CBO) to get facilities from the government subsidy schemes. Particularly fishing gear and housing facilities for fishers are provided through the CBO. Fisheries and Aquatic Resources Act of 1996 provides adequate legal provisions for management of fisheries. Theses legal provisions emphasis registration of fishing craft, obtaining license for fisheries operations, prohibiting use of gear specified as illegal etc. Fisheries and Aquatic Resources Act of 1996 section VI explains the legal foundation for co-management arrangement. Some certain areas have been declared as special area for management under this provision. Further, these provisions include facilitation of fishing communities in fisheries management and decision making. State fisheries authority is the centralized management authority which implements management systems through extension officers of the National Aquaculture Development Authority of Sri Lanka. Even though adequate legal framework for management of fisheries exists in Sri Lanka, use of illegal fishing gear and fishing by unauthorized fishers are very high.

\section{Key factors for successful small-scale fisheries management in Sri Lanka}

The following factors are essential for successful of smallscale fisheries management, but this is not a list of entire factors. Merely few of them are elaborated here. Each of these factors is operating alongside a number of other factors. Providing appropriate Incentives will promote management practice in small-scale fisheries in Sri Lanka. In some cases, incentives will lead to over-exploitation where fisheries are poorly managed. The real challenge to the management authorities in Sri Lanka is to run an appropriate management system that prevent awkward incentives and discourage exploitation. Use right system can be introduced to have proper incentives. Defining use rights helps to achieve success in many ways. However, stakeholders should consider that use rights are equitable and a fair means of controlling efforts to continue success. A well-structured Institutional arrangement and enough capacity are very critical for small-scale fisheries management. Understanding institutional approaches in small-scale fisheries put forward in the recent decades in Sri Lanka. Institutional approaches emphasize that those fisheries managers need to understand how wide-range of institutional arrangement have impacts upon fishery. Small-scale fisheries in Sri Lanka lack institutional capacity. Even so, there are some success stories as well.

A holistic management approaches should be added in planning and stakeholder participation. A fishery is one part of livelihood strategy on the coastal area of Sri Lanka which cannot function in isolation. Therefore, fisheries management should recognize multi-sectorial approaches to take into account the interest and impacts of related sectors. Generally, other sectors will negatively impact the fishery sector but possible negatives should be taken positively to avoid challenges to the management system. Complexity and change in smallscale fisheries management must smoothly be dealt. Fisheries are diverse and complex system in Sri Lanka which requires flexibility to manage such as complex system.

Vertical and horizontal cooperation need to be built in small-scale fisheries management in Sri Lanka. It is essential to build up horizontal cooperation between fishers and vertical cooperation between fishers and management (state) to demonstrate success. This can be manifested through comanagement approach. Introducing resource rent is a critical contributor to success in fisheries management. Fisheries can be managed effectively from the collection of resource rent. In addition, social objectives of fisheries management plan can be fulfilled through collection of resource rent. National policy frameworks should be formulated to manage natural resources in Sri Lanka. The success of management objectives depends on the strength, flexibility and appropriateness of framework.

\section{Conclusion}

Three should be more closure and practical links between Scientists, NGOs, and fisheries managers to improve management of small-scale fisheries in Sri Lanka. Further, better balance need to be kept between input and output control measures to reduce pressure on fishing in Sri Lanka. Management in smallscale fisheries heavily depends on output controls rather than considering exploitation pressures. Input control should be used with other regulatory measures. Therefore, it is very important 
to impose a balance set of both input and output controls. Development is the main issue in Sri Lanka. Development projects cause exploitation of natural resources and environment but NGOs have involved in the conservation activities. In some cases, managers are forced to control the over-exploitation on fishing after exploitation went out of control. Fisheries cannot manage sustainably if fishing pressure continue at full pace. Small-scale fisheries managers can introduce strict on number of fishers, boats or days to curtail exploitation by fishers. However, fisheries are very important for the welfare, livelihood and finical security of the coastal poor [30]. Falling to control fishing capacity in small-scale fisheries will cause overfishing and loss of livelihoods, biodiversity and ecosystem. Management issues in small-scale fisheries in Sri Lanka need to be address culturally and context specific.

\section{References}

1. Pomeroy RS (2001) Devolution and fisheries co-management. In Meinzen-Dick R, Knox A, Di Gregorio M (Eds.), Collective Action, Property Rights and Devolution of Natural Resource Management - Exchange of Knowledge and Implications for Policy. Feldafing Germany, pp. 111-146.

2. Pálsson G (1989) The art of fishing. MAST. Maritime anthropological studies 2: 1-20.

3. Berkes F (2007) Adaptive Co-Management and Complexity: Exploring the Many Faces of Co-Management. In: Armitage D Doubleday N (Eds.) Adpative Co-Management. UBC Press, Vancouver, Canada, pp. 1937.

4. CRS (2006) Fisheries Opportunities Assessment. University of Rhode Island and Florida International University, USA.

5. Mills DJ, Westlund L, De Graaf G, Kura Y, Willman R, et al. (2011) Underreported and undervalued: small-scale fisheries in the developing world. In: Pomeroy RS, Andrew NL (Eds.), Small-Scale Fisheries Management: Frameworks and Approaches for the Developing World. CABI International, England, pp.1-15.

6. Kura Y, Revenga C, Hoshino E, Mock G (2004) Fishing for Answers: Making Sense of the Global Fish Crisis. World Resource Institute, Washington, DC, USA.

7. Ministry of Fisheries and Aquatic Resource Development (2016) Fisheries annual statistics 2016. Colombo.

8. Berkes F, Mahon R, McConney P, Pollnac R, Pomeroy R (2001) Managing Small-scale Fisheries: Alternative Directions and Methods. International Development Research Centre, Ottawa, Canada.

9. Pomeroy RS (2015) Linking science and people: applying socioeconomic and governance science to solve problems and create opportunities in Caribbean fisheries. In Proceedings of the 67th Gulf and Caribbean Fisheries Institute Conference (Barbados).

10. Pomeroy RS, Katon BM, Harkes I (2001) Conditions affecting the success of fisheries co-management: lessons from Asia. Marine Policy 25(3): 197-208.

11. Evans L, Cherrett N, Pemsl D (2011) Assessing the impact of fisheries co-management interventions in developing countries: A metaanalysis. J Environ Manage 92(8):1938-1949.

12. Pomeroy R, Berkes F (1997) Two to tango: the role of government in fisheries co-management. Marine Policy 21(5): 465-480.
13. Jentoft S (2003) Co-management the way forward. In: Wilson DC, Nielsen JR, Degnbol D (Eds.), Fisheries Co-Management Experiences. Kluwer Academic, Dordrecht, The Netherlands, p.1-14.

14. Hanna S (1995) Efficiencies of User Participation in Natural Resource Management. In Property Rights and the Environment, Social and Ecological Issues. Beijer International Institute of Ecological Economics and the World Bank. Washington DC, USA.

15. Jentoft S (1989) Fisheries co-management- delegating government responsibility to fishermen organizations. Marine Policy 13(2): 137154.

16. Gutierrez NL, Hilborn R, Defeo U (2011) Leadership, social capital and incentives promote successful fisheries. Nature 470(7334): 386-389.

17. Purcell SW (2014) Value, Market Preferences and Trade of Beche-DeMer from Pacific Island Sea Cucumbers. PLoS ONE 9(4): e95075.

18. Cinner JE, McClanahan TR, MacNeil MA, Graham NAJ, Daw TM, et al (2012) Co-management of coral reef social-ecological systems. Proc Natl Acad Sci U S A 109(14): 5219-5222.

19. Purcell SW, Lovatelli A, Pakoa K (2014) Constraints and solutions for managing Pacific Island sea cucumber fisheries with an ecosystem approach. Marine Policy 45: 240-250.

20. Purcell SW (2010) Managing Sea Cucumber Fisheries with an Ecosystem Approach. FAO Fisheries and Aquaculture Technical Paper No. 520. FAO, Rome, Italy.

21. Laugen AT, Engelhard GH, Whitlock R, Arlinghaus R, Dankel DJ et al. (2014) Evolutionary impact assessment: accounting for evolutionary consequences of fishing in an ecosystem approach to fisheries management. Fish and Fisheries 15(1): 65-96.

22. Salas S, Chuenpagdee R, Seijo JC, Charles A (2007) Challenges in the assessment and management of small-scale fisheries in Latin America and the Caribbean. Fisheries and Research 87(1): 5-16.

23. Copes P (1986) Critical Review of the Individual Quota as a Device in Fisheries Management. Land Economics 62(3): 278-291.

24. Pomeroy RS (2011) Managing overcapacity in small-scale fisheries. In: Pomeroy RS, Andrew NL (Eds.), Small-Scale Fisheries Management: Frameworks and Approaches for the Developing World. CAB International, Oxfordshire, England, pp. 75-92.

25. Sadovy Y (2005) Trouble on the reef: the imperative for managing vulnerable and valuable fisheries. Fish and Fisheries 6(3): 167-185.

26. Pomeroy RS (2012) Managing overcapacity in small-scale fisheries in Southeast Asia. Marine Policy 36(2): 520-527.

27. Castilla JC, Gelcich S, Defeo O (2007) Successes, lessons, and projections from experience in marine benthic invertebrate artisanal fisheries in Chile. In: McClanahan TR, Castilla JC (Eds.), Fisheries Management: Progress Towards Sustainability, Blackwell Publishing Ltd., Oxford, UK, England, pp. 23-42.

28. Bertram I (1995) The Aitutaki experience in the development of management strategies for the trochus fishery. SPC Trochus Information Bulletin 4: 42-47.

29. Johnson AE, Cinner JE, Hardt MJ, Jacquet J, McClanahan TR, et al (2013) Trends, current understanding and future research priorities for artisanal coral reef fisheries research. Fish and Fisheries 14(3): 281-292.

30. Béné C, Hersoug B, Allison EH (2010) Not by rent alone: analyzing the pro-poor functions of small-scale fisheries in developing countries. Development Policy Review 28(3): 325-358. 
Your next submission with Juniper Publishers will reach you the below assets

- Quality Editorial service

- Swift Peer Review

- Reprints availability

- E-prints Service

- Manuscript Podcast for convenient understanding

- Global attainment for your research

- Manuscript accessibility in different formats ( Pdf, E-pub, Full Text, Audio)

- Unceasing customer service

Track the below URL for one-step submission https://juniperpublishers.com/online-submission.php 